\title{
Sistem Pakar Fuzzy Untuk Optimasi Penggunaan Bandwidth Jaringan Komputer
}

\author{
${ }^{a}$ Mustaziri \\ a Jurusan Teknik Komputer, Politeknik Negeri Sriwijaya \\ Palembang, Indonesia 30139
}

\begin{abstract}
The need for bandwidth availability today is very high along with the increase of infrastructural growth of internet network. Therefore, the presence of efficient, reliable, and economical service availability system is required. It can be achieved by performing good and appropriate system planning. In providing efficient and reliable internet services, one of the supporting factors is the optimization of bandwidth using. To optimize the use of bandwidth, we use fuzzy expert system by Sugeno method. This fuzzy expert system use 3 input variables, such as lecture room, day, and time, with one output variable of the capacity of bandwidth used. Rule base being made based on the consultation with the expert to determine the rule base for fuzzy system input. The computation to determine the average error using the computation formula of MAPE (Means Absolute Percentage Error) which is the error median of absolute percentage. The data of the research results on the optimization of bandwidth using in fuzzy expert system with Sugeno method obtain from verification, that is by comparing actual data to prediction data with fuzzy system. The average error result is $6,5142 \%$.
\end{abstract}

Keywords: Fuzzy Expert System; Optimization; Bandwidth

\section{Pendahuluan}

Beberapa tahun terakhir ini telah berkembang aplikasi multimedia dan teknologi telekomunikasi, ini dapat dilihat dengan meningkatannya jumlah pengguna teknologi informasi terutama jaringan komputer untuk mengkases internet. Oleh karena itu, jaringan komputer diharapkan memainkan peran penting untuk akses internet melakukan layanan transaksional dan akses aplikasi multimedia yang bergerak, serta untuk mendukung berbagai komunikasi.

Pada jaringan komputer, antrian telah menjadi paradigma oleh karena itu adanya penjadwalan yang menyediakan beberapa persyaratan quality of service, yaitu keluaran dan delay yang dibatasi. Akibatnya algoritma penjadwalan diusulkan untuk melayani secara porporsional bagi pengguna jaringan komputer.

Lembaga pendidikan tinggi di negara-negara berkembang harus berhadapan dengan tuntutan terhadap pertumbuhan infrastruktur internet. Berkembangnya jaringan Local Area Network (LAN) dan jaringan internet yang semakin membesar membutuhkan adanya suatu metode yang dapat memprediksi dan mengindentifikasi kebutuhan bandwidth jaringan komputer, sehingga dapat meningkatkan kualitas layanan akademik dan menentukan berapa besar biaya yang akan dikeluarkan untuk sewa bandwidth.

Penggunaan sistem pakar fuzzy telah banyak dimanfaatkan dalam beberapa penelitian dengan tingkat kesalahan yang relatif sedikit, karena pada sistem pakar fuzzy dapat mengolah data yang banyak dengan data yang memiliki rentang sehingga mempermudah perhitungan untuk memperoleh hasil, logika fuzzy juga sangat fleksibel

Email : mustaziri@yahoo.co.id artinya mampu beradaptasi dengan perubahan-perubahan dan ketidakpastian yang menyertai permasalahan, serta mampu memodelkan fungsi non linier yang sangat kompleks dan dapat membangun dan mengaplikasikan pengalaman-pengalaman para pakar secara langsung tanpa harus melalui proses pelatihan.

Penelitian ini bertujuan untuk membuat sistem optimasi penggunaan bandwidth jaringan komputer menggunakan sistem pakar fuzzy dengan metode Sugeno untuk mengidentifikasi penggunaan bandwidth jaringan komputer.

\section{Kerangka Teori}

\subsection{Jaringan Komputer}

Jaringan komputer adalah dua atau lebih komputer yang saling terhubung, bisa berbagi pakai file dan peralatan jaringan pada beberapa lokasi . Pada jaringan komputer terdapat istilah bandwidth. Bandwidth adalah suatu ukuran rentang frekuensi maksimum yang dapat mengalir data dari suatu tempat ke tempat lain dalam suatu waktu tertentu.Satuan yang dipakai untuk Bandwidth adalah bit per secon (bps) atau Byte persecon (Bps) dimana 1 Byte $=8$ bit. Bit atau binary digit adalah basis angka yang terdiri dari angka 0 dan 1. Satuan ini menggambarkan seberapa banyak bit (angka 0 dan 1) yang dapat mengalir dari satu tempat ke tempat yang lain dalam setiap detiknya melalui suatu media (Hekmat, 2005)..

\subsection{Internet}

Internet merupakan singkatan dari Interconected Networking, yang berarti suatu jaringan komputer yang terhubung dengan luas. Internet berasal dari sebuah jaringan komputer yang dibuat pada tahun 1970-an yang 
terus berkembang sampai sekarang menjadi jaringan dunia yang sangat luas. Jaringan tersebut diberi nama ARPANET, yaitu jaringan yang dibentuk oleh Departemen Pertahanan Amerika Serikat. Kemudian, jaringan komputer tersebut diperbaharui dan dikembangkan sampai sekarang dan menjadi tulang punggung global untuk sumber daya informasi yang disebut internet (Andrew, 1997).

\subsection{Sistem Pakar Fuzzy}

Sistem pakar merupakan suatu sistem terkomputerisasi yang menggunakan pengetahuan bidang tertentu untuk mencapai solusi suatu masalah dari bidang tersebut. Sistem pakar dalam memecahkan masalah menggunakan proses yang serupa dengan metode yang digunakan seorang pakar. Solusi yang diberikan sistem pakar pada dasarnya sama seperti yang disimpulkan oleh seorang pakar. (Hartati dan Iswari, 2008).

\subsection{Metode Sugeno}

Penalaran dengan metode output (konsekuen) sistem tidak berupa himpunan fuzzy, melainkan berupa konstanta atau persamaan linear. Metode ini diperkenalkan oleh Takagi-Sugeno Kang pada tahun 1985 Perbedaan utama antara metode Mamdani dan Sugeno adalah output membership function dari metode Sugeno berbentuk linier atau konstan (Kusumadewi, 2010).

Aturan pada model fuzzy Sugeno mempunyai bentuk :

If Input $1=\mathrm{x}$ and Input $2=\mathrm{y}$

then Output is $z=a x+b y+c$

Ada 2 model fuzzy dengan metode Sugeno yaitu sebagai berikut:

1. Model Fuzzy Sugeno Orde-Nol

Secara umum bentuk model fuzzy SUGENO Orde-Nol adalah:

$\operatorname{IF}\left(x_{1}\right.$ is $\left.A_{1}\right) \bullet\left(x_{2}\right.$ is $\left.A_{2}\right) \bullet\left(x_{3}\right.$ is $\left.A_{3}\right) \bullet \ldots \cdot\left(x_{N}\right.$ is $\left.A_{N}\right)$ HEN $z=k$ dengan $A_{i}$ adalah himpunan fuzzy ke-i sebagai anteseden, dan $\mathrm{k}$ adalah suatu konstanta (tegas) sebagai konsekuen.

2. Model Fuzzy Sugeno Orde-Satu

Secara umum bentuk model fuzzy SUGENO Orde-Satu adalah:

$\operatorname{IF}\left(\mathrm{x}_{1}\right.$ is $\left.\mathrm{A}_{1}\right) \cdot \ldots \cdot\left(\mathrm{x}_{\mathrm{N}}\right.$ is $\left.\mathrm{A}_{\mathrm{N}}\right)$ THEN $\mathrm{z}=\mathrm{p}_{1} * \mathrm{x}_{1}+\ldots+\mathrm{p}_{\mathrm{N}} * \mathrm{x}_{\mathrm{N}}+\mathrm{q}$

\subsection{Pengukuran Prakiraan}

Teknik Prakiraan tidak selamanya selalu tepat karena teknik prakiraan yang digunakan belum tentu sesuai dengan sifat datanya, atau disebabkan oleh kondisi di luar bisnis yang mengharuskan bisnis itu menyesuaikan diri. Oleh karena itu, perlu diadakan pengawasan prakiraan sehingga dapat diketahui sesuai atau tidaknya teknik prakiraan yang digunakan. Sehingga dapat dipilih dan ditentukan teknik prakiraan yang lebih sesuai dengan cara menentukan batas toleransi peramalan atas penyimpangan yang terjadi.

Pada prinsipnya, pengawasan prakiraan dilakukan dengan membandingkan hasil prakiraan dengan kenyataan yang terjadi. Penggunaan teknik prakiraan yang menghasilkan penyimpangan terkecil adalah teknik prakiraan yang paling sesuai untuk digunakan.

Besarnya error peramalan dihitung dengan mengurangi data riil dengan besarnya ramalan. Keterangan:
Error $(E)=X_{t}-F_{t}$

$\mathrm{X}_{\mathrm{t}}=$ Data riil periode ke- $\mathrm{t}$

$\mathrm{F}_{\mathrm{t}}=$ Ramalan periode ke- $\mathrm{t}$

Dalam menghitung error peramalan digunakan MAPE (Means Absolute Percentage Error)

Mean Absolute Percentage Error (MAPE) merupakan nilai tengah kesalahan persentase absolute dari suatu peramalan.

$$
\text { MAPE }=\frac{\sum_{t=1}^{n} \frac{\left|X_{t}-F_{t}\right|}{X_{t}}}{n}
$$

Keterangan:

$\mathrm{X}_{\mathrm{t}}=$ Nilai data periode ke- $\mathrm{t}$

$\mathrm{F}_{\mathrm{t}}=$ Ramalan periode ke- $\mathrm{t}$

$\mathrm{n}$ = Banyaknya data

Jika MAPE $<\mathbf{2 5 \%}$ maka hasil simulasi dapat diterima secara memuaskan, sebaliknya jika MAPE > 25\% maka hasil simulasi kurang memuaskan (Oktafri, 2001).

\section{Metodologi}

\subsection{Prosedur Penelitian}

Prosedur penelitian akan mengikuti jalannya diagram alur penelitian yang merupakan acuan dari penelitian berikut ini prosedur penelitian seperti pada gambar 1 .

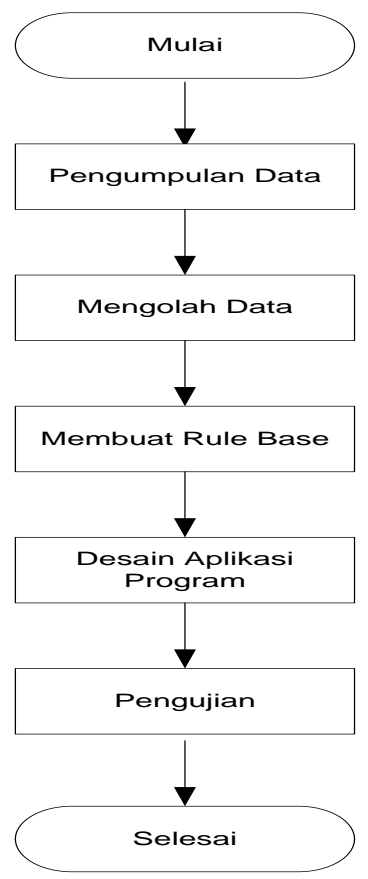

Gambar 1 Diagram Alur Penelitian

\subsection{Kerangka Kerja Sistem}

Rencananya kerangka kerja dari sistem pakar fuzzy untuk optimasi penggunaan bandwidth yang akan dibagun dimulai dari pengambilan data pengguna bandwidth, kemudian pengelompokkan data, setelah itu desain rule base dengan keluaran kapasitas bandwidth pada gedung kuliah di hari dan waktu sang yang sama. Untuk lebih 
jelasnya mengenai kerangka kerja sistem dapat dilihat dapat dilihat pada gambar 2.

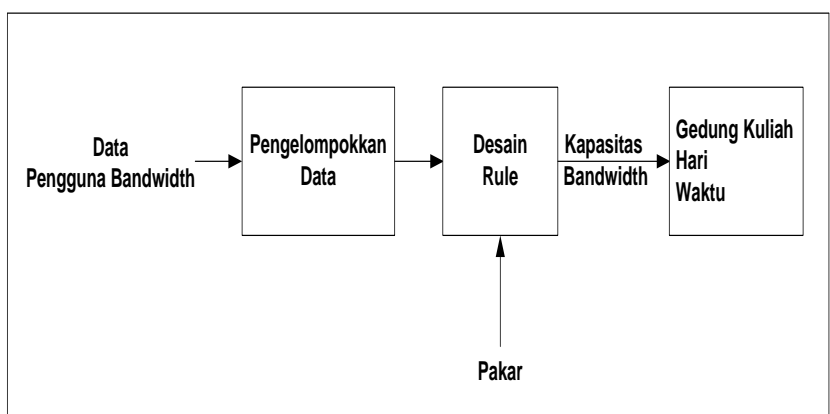

Gambar 2. Diagram Blok Optimasi penggunaan Bandwidth

\subsection{Aturan Fuzzy Optimasi Penggunaan Bandwith}

Pada pembentukan aturan fuzzy dengan metode Sugeno dengan data yaitu terdiri dari lokasi gedung hari dan waktu kapasitas bandwidth yang terpakai pada setiap gedung data yang digunakan yaitu data pengguna bandwidth selama 3 bulan. Proses pembentukan aturan fuzzy berfungsi untuk membuat rule base yang digunakan untuk acuan dalam pembuatan logika pada program aplikasi yang akan dibuat. Metode inferensi fuzzy yang digunakan adalah metode Sugeno orde nol karena pada metode ini anteseden dipresentasikan dengan proposisi dalam himpunan fuzzy, sedangkan konsekuen direprensentasikan dengan sebuah konstanta. Berikut ini contoh rule base yang digunakan untuk optimasi penggunaan bandwidth jaringan komputer.

IF Gedung Kuliah And hari And waktu THEN Bandwidth Terpakai

\section{Hasil dan Pembahasan}

\subsection{Hasil}

Aplikasi sistem optimasi penggunaan bandwidth jaringan komputer di Politeknik Negeri Sriwijaya menggunakan sistem pakar fuzzy dengan metode Sugeno dengan bahasa pemrograman Visual basic 2010, telah berhasil dibuat. Tampilan halaman aplikasi sistem optimasi penggunaan bandwidth telah sesuai dengan desain dan perancangan antarmuka yang ditunjukkan pada GambarGambar sebagai berikut:

1. Menu Utama

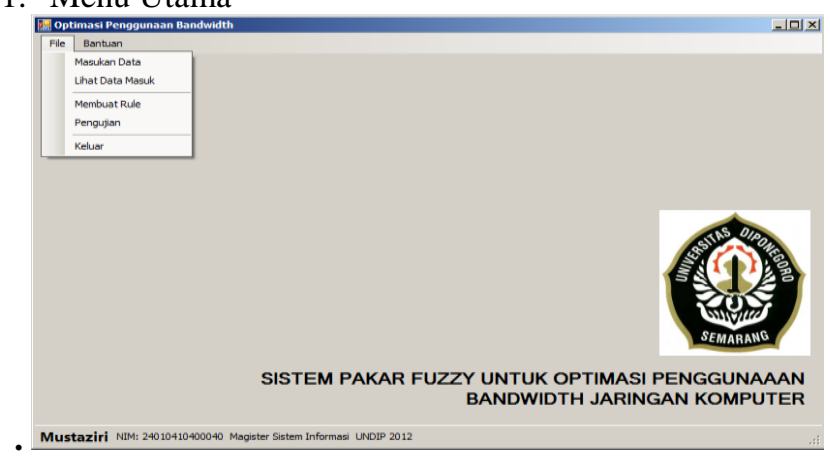

Gambar 3. Menu Utama

Pada jendela menu utama terdapat beberapa pilihan item yang dapat digunakan, yaitu masukan data, lihat data masuk, membuat rule, pengujian dan keluar yang berfungsi untuk keluar dari program aplikasi ini. Sehingga mempermuda penggunaan aplikasi ini dengan klik salah satu item maka akan keluar jendela yang di klik tadi.

\section{Menu Masukan Data}

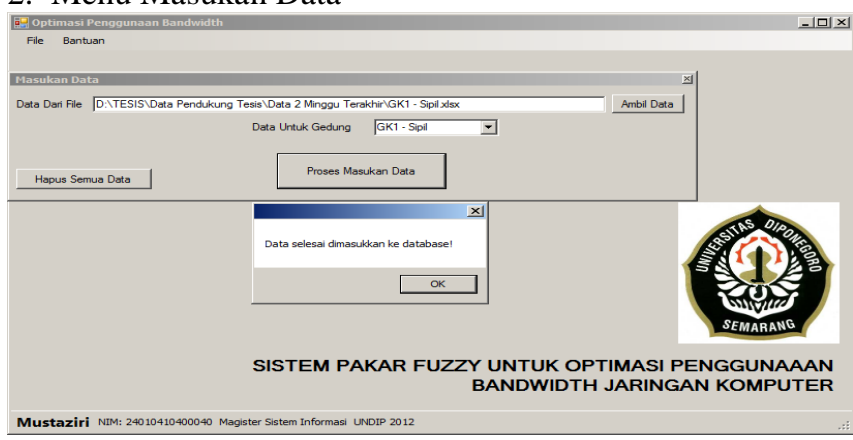

Gambar 4. Menu Masukan Data

Pada jendela menu utama terdapat beberapa pilihan item yang dapat digunakan, yaitu masukan data, lihat data masuk, membuat rule, pengujian dan keluar yang berfungsi untuk keluar dari program aplikasi ini. Sehingga mempermuda penggunaan aplikasi ini dengan klik salah satu item maka akan keluar jendela yang di klik tadi.

\section{Menu Masukan Data}

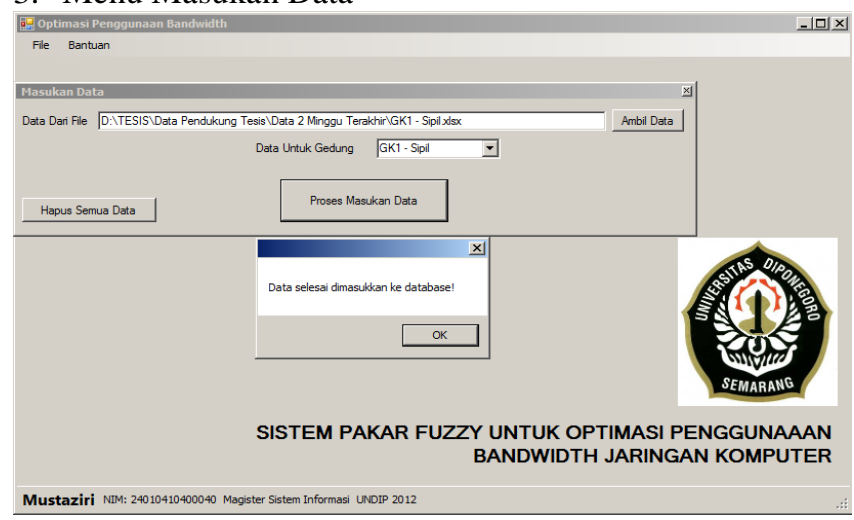

Gambar 5. Menu Masukan Data

Menu Masukan Data berfungsi untuk memasukan atau mengambil data dari direktori tempat penyimpanan data dengan cara klik tombol di sebelah kanan data dari file yaitu tombol "ambil data " pada menu masukan data maka akan langsung diarahkan ke direktori tempat menyimpan data, data masih dalam format Microsoft exel kemudian pilih data yang akan dimasukan ke data base yaitu my sql, lalu pilih data dari gedung mana yang akan dimasukan ke data base dengan memilih nama gedung, selanjutnya tekan tombol "proses masukan data" yang berfungsi memulai proses memasukan data, tunggu beberapa saat sampai proses memasukan data selesai, apabila data telah selesai maka akan muncul jendela informasi yang memberitahukan bahwa data telah selesai dimasukan ke data base. Untuk lebih jelas mengenai menu masukkan data dapat dilihat pada Gambar 5. 


\section{Menu Membuat Rule}

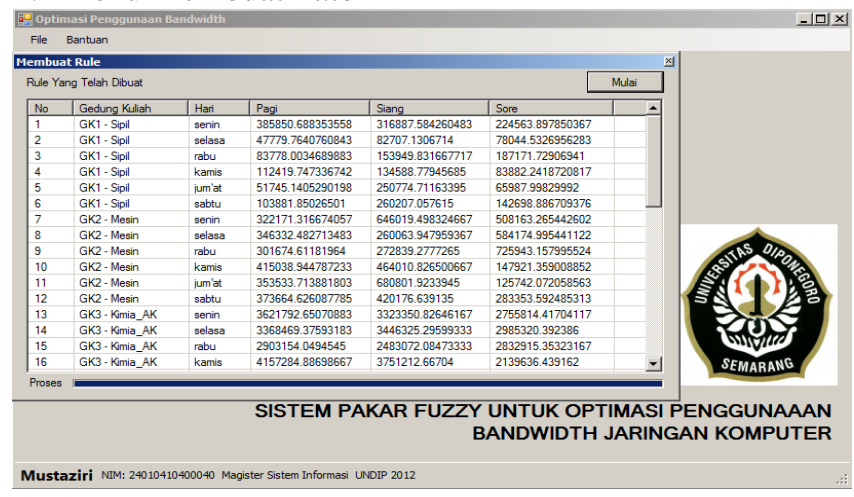

Gambar 6. Menu Membuat Rule

Menu Membuat Rule seperti pada Gambar 4.4 adalah proses pembuatan rule pada data yang telah dimasukan ke data base my sql, data yang belum di kelompokan maka dengan membuat rule, data akan di kelompokan berdasarkan hari yaitu dari hari senin sampai sabtu berdasarkan waktu pagi, siang dan sore dan terdapat gedung kuliah yaitu GK1 Sipil, GK2 Mesin, GK3 Kimia/AK, GK4 Adm, GK5 Elektro dan GK6 TK/MI, dan terdapat juga no, yaitu urutan hasil proses pembuatan rule yang dengan metode Sugeno yang berfungsi sebagai acuan algoritma pembuatan program yang akan mendapatkan keluaran yaitu informasi kapasitas bandwidth, untuk memulai membuat rule klik tombol "mulai" pada menu membuat rule kemudian akan terlihat proses pembuatan rule ditandai warna biru bergerak ke kanan tunggu sampai selesai itu bearti proses pembuatan rule telah selesai dan hasilnya seperti pada Gambar 6.

\section{Menu Pengujian}

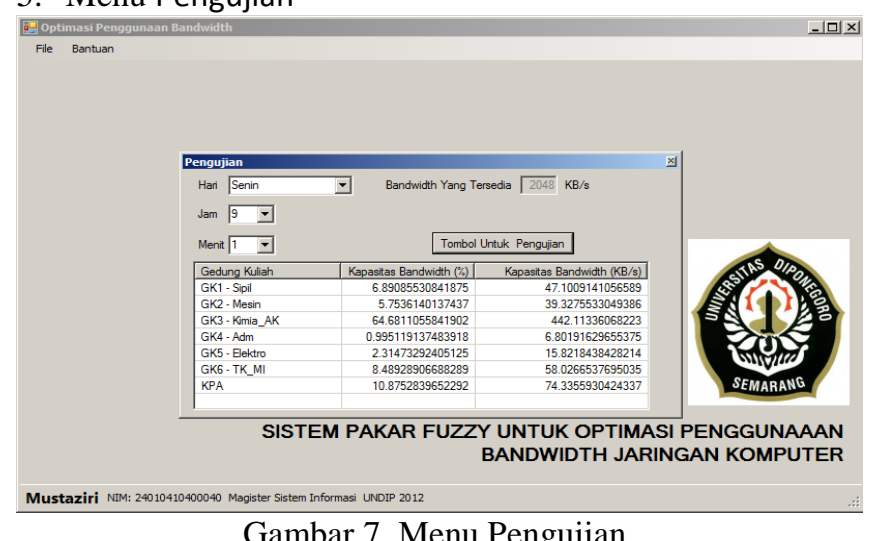

Menu berikutnya adalah menu Pengujian, pada menu pengujian terdapat informasi hari saat pengujian, jam dan menit saat pengujian yang disesuaikan dengan format waktu yang pada BIOS laptop yang dipakai saat melakukan pengujian. Pada menu pengujian juga terdapat informasi bandwidth yang tersedia. Untuk memulai porses pengujian dengan klik "tombol untuk pengujian" maka akan terlihat hasil pengujian yaitu berupa lokasi gedung kuliah, jumlah bandwidth yang terpakai dalam format absolute dan persentase $(\mathrm{kb} / \mathrm{s})$, untuk lebih jelasnya dapat dilihat pada Gambar 7.

\subsection{Pembahasan}

\subsubsection{Proses Pemasukan Data ke Fuzzy}

Data yang digunakan untuk optimasi penggunaan bandwidth adalah data historis pengguna bandwidth jaringan komputer selama 3 bulan yang akan digunakan untuk input sistem fuzzy, Data yang digunakan untuk proses input data adalah data bulan Januari sampai Maret 2012 mulai jam 7.00 sampai jam 19.00 kemudian data kelompokan berdasarkan waktu yaitu Pagi, Siang dan Sore.

Proses pengelompokan data dibuat menggunakan rule base yang menjadi telah dibahas pada bab sebelumnya. Pembuatan rule base berdasarkan algoritma fuzzy dengan metode Sugeno, begitu juga dengan pengelompokan data yang berfungsi sebagai input yang akan digunakan oleh proses fuzzy. Berikut ini contoh data input pada tabel 4.1 yaitu data selama satu minggu yaitu dari tanggan 9 Januari sampai 14 Januari 2012.

Tabel 1. Data input fuzzy pada GK1 Sipil

\begin{tabular}{|l|l|l|l|}
\hline Tangga1/Jam & Bandwith(bit/s) & Tanggal/Jam & Bandwith(bit/s) \\
\hline $4 / 23 / 20127: 00$ & 448.3329 & $4 / 26 / 20127: 00$ & 102139.1 \\
\hline $4 / 23 / 20129: 00$ & 1774963 & $4 / 26 / 20129: 00$ & 415307.8 \\
\hline $4 / 23 / 201211: 00$ & 452394.3 & $4 / 26 / 201211: 00$ & 47595.8 \\
\hline $4 / 23 / 201213: 00$ & 286427.2 & $4 / 26 / 201213: 00$ & 25632.17 \\
\hline $4 / 23 / 201215: 00$ & $284(31.5$ & $4 / 26 / 201215: 00$ & 3780.052 \\
\hline $4 / 23 / 201217: 00$ & 244904.8 & $4 / 26 / 201217: 00$ & 107479 \\
\hline $4 / 23 / 201219: 00$ & 673540.6 & $4 / 26 / 201219: 00$ & 2051.657 \\
\hline $4 / 24 / 20127: 00$ & 454.539 & $4 / 27 / 20127: 00$ & 1032.217 \\
\hline $4 / 24 / 20129: 00$ & 32266.51 & $4 / 27 / 20129: 00$ & 148136.1 \\
\hline $4 / 24 / 201211: 00$ & 121685.9 & $4 / 27 / 201211: 00$ & 68277.34 \\
\hline $4 / 24 / 201213: 00$ & 70645.77 & $4 / 27 / 201213: 00$ & 839376.6 \\
\hline $4 / 24 / 201215: 00$ & 110529.9 & $4 / 27 / 201215: 00$ & 473738.2 \\
\hline $4 / 24 / 201217: 00$ & $168(778.6$ & $4 / 27 / 201217: 00$ & 2772.86 \\
\hline $4 / 24 / 201219: 00$ & 140952 & $4 / 27 / 201219: 00$ & 4742.743 \\
\hline $4 / 25 / 20127: 00$ & 457.3873 & $4 / 28 / 20127: 00$ & 449.7551 \\
\hline $4 / 25 / 20129: 00$ & $253(77.1$ & $4 / 28 / 20129: 00$ & 182242.8 \\
\hline $4 / 25 / 201211: 00$ & 148909.2 & $4 / 28 / 201211: 00$ & 375359 \\
\hline $4 / 25 / 201213: 00$ & 124019.7 & $4 / 28 / 201213: 00$ & 72722.92 \\
\hline $4 / 25 / 201215: 00$ & 248676.9 & $4 / 28 / 201215: 00$ & 1113160 \\
\hline $4 / 25 / 201217: 00$ & 291626.2 & $4 / 28 / 201217: 00$ & 1183.651 \\
\hline $4 / 25 / 201219: 00$ & 225729.4 & $4 / 28 / 201219: 00$ & 2360188.9 \\
\hline & & &
\end{tabular}

Kemudian data akan dikelompokan berdasarkan hari yaitu senin sampai sabtu dan berdasarkan waktu yaitu Pagi dari jam 7.00 sampai jam 10.00 Siang dari jam 11.00 sampai jam 13.00 dan Sore dari jam 14.00 sampai jam 19.00 serta berdasarkan gedung yaitu, G KPA, GK1 Sipil GK2 Mesin GK3 Kimia/AK GK4 Adm GK5 Elektro dan GK6 TK/MI. Berikut ini contoh data yang telah di kelompokan sebagai data input untuk proses fuzzy, data untuk satu minggu padaG KPA seperti pada tabel 2. 
Tabel 2. Pengelompokan data untuk input fuzzy

\begin{tabular}{|c|c|c|c|}
\hline Gedung & Hari & Waktu & Bandwidth(KB/s) \\
\hline \multirow{18}{*}{ GK1 Sipil } & \multirow{3}{*}{ Senin } & Pagi & 460079 \\
\hline & & Siang & 316887.6 \\
\hline & & Sore & 224563.9 \\
\hline & \multirow{3}{*}{ Selasa } & Pagi & 39737.63 \\
\hline & & Siang & 82707.13 \\
\hline & & Sore & 78044.53 \\
\hline & \multirow{3}{*}{ Rabu } & Pagi & 68729.87 \\
\hline & & Siang & 153949.8 \\
\hline & & Sore & 187171.7 \\
\hline & \multirow{3}{*}{ Kamis } & Pagi & 149437.5 \\
\hline & & Siang & 134588.8 \\
\hline & & Sore & 83882.24 \\
\hline & \multirow{3}{*}{ Jumat } & Pagi & 37752.27 \\
\hline & & Siang & 250774.7 \\
\hline & & Sore & 65988 \\
\hline & \multirow{3}{*}{ Sabtu } & Pagi & 61983.04 \\
\hline & & Siang & 260207.1 \\
\hline & & Sore & 142698.9 \\
\hline
\end{tabular}

Setelah pengelompokan data berikutnya adalah memasukan data ke proses fuzzy untuk membuat rule yang berrfungsi untuk aturan yang akan digunakan dan keluarannya berupa informasi kapasitas bandwidth yang digunakan pada setiap gedung kuliah.

\subsection{Pengujian}

Pengujian data penggunaan bandwidth dari tanggal 5 Januari sampai tanggal 31 Maret 2012 dilakukan dengan cara memasukan data melalui form masukan data kemudian data dikelompokan menjadi hari yaitu senin sampai sabtu dan waktu pagi siang sore setelah itu data masuk ke data base my sql lalu dilakukan pembuatan rule lalu baru dilakukan pengujian. Output dari hasil pengujian aplikasi sistem optimasi pengguna bandwidth terdiri hari pengujian jam pengujian menit pengujian serta bandwidth yang tersedia dan tombol untuk memulai pengujian, apabila tombol untuk memulai pengujian di klik maka hasil yang diperoleh adalah data hasil pengujian yaitu informasi pemakaian bandwidth terdiri dari lokasi yaitu gedung kuliah serta jumlah bandwidth yang terpakai, seperti pada tabel 3 sampai tabel 20.

Tabel 3. Hasil pengujian Hari Senin Pagi

\begin{tabular}{|c|c|c|}
\hline Gedung & Kapasitas Bandwidth (\%) & Kapasitas Bandwidth (KB/s) \\
\hline GK1 - Sipil & 6.6438 & 46.1105 \\
\hline GK2 - Mesin & 6.2257 & 43.9784 \\
\hline GK3 - Kimia_AK & 62.9828 & 437.8273 \\
\hline GK4 - Adm & 1.0995 & 7.7900 \\
\hline GK5 - Elektro & 2.3884 & 16.7545 \\
\hline GK6 - TK_MI & 8.8666 & 62.3108 \\
\hline KPA & 11.7928 & 83.3288 \\
\hline
\end{tabular}

Tabel 4. Hasil pengujian Hari Senin Siang

\begin{tabular}{|c|c|c|}
\hline Gedung & Kapasitas Bandwidth (\%) & Kapasitas Bandwidth (KB/s) \\
\hline GK1 - Sipil & 6.8908 & 47.1009 \\
\hline GK2 - Mesin & 5.7536 & 39.3275 \\
\hline GK3 - Kimia_AK & 64.68118 & 442.1133 \\
\hline GK4 - Adm & 0.9951 & 6.80197 \\
\hline GK5 - Elektro & 2.31474 & 15.8218 \\
\hline GK6 - TK_MI & 8.48927 & 58.0266 \\
\hline KPA & 10.87527 & 74.3355 \\
\hline
\end{tabular}

Tabel 5. Hasil pengujian Hari Senin Sore

\begin{tabular}{|c|c|c|}
\hline Gedung & Kapasitas Bandwidth (\%) & Kapasitas Bandwidth (KB/s) \\
\hline GK1 - Sipil & 3.9862 & 31.1692 \\
\hline GK2 - Mesin & 8.6622 & 67.6410 \\
\hline GK3 - Kimia_AK & 46.0686 & 359.496 \\
\hline GK4 - Adm & 0.9901 & 7.8405 \\
\hline GK5 - Elektro & 6.4073 & 49.4261 \\
\hline GK6 - TK_MI & 9.2012 & 72.0375 \\
\hline KPA & 24.6840 & 191.4530 \\
\hline
\end{tabular}

Tabel 6. Hasil pengujian Hari Selasa Pagi

\begin{tabular}{|c|c|c|}
\hline Gedung & Kapasitas Bandwidth (\%) & Kapasitas Bandwidth (KB/s) \\
\hline GK1 - Sipil & 0.4778 & 5.8324 \\
\hline GK2 - Mesin & 3.4640 & 42.2769 \\
\hline GK3 - Kimia_AK & 33.6913 & 411.1901 \\
\hline GK4 - Adm & 1.7884 & 21.8278 \\
\hline GK5 - Elektro & 1.9723 & 24.0714 \\
\hline GK6 - TK_MI & 4.0269 & 49.1478 \\
\hline KPA & 54.5789 & 666.1142 \\
\hline
\end{tabular}

Tabel 7. Hasil pengujian Hari Selasa Siang

\begin{tabular}{|c|c|c|}
\hline Gedung & Kapasitas Bandwidth (\%) & Kapasitas Bandwidth (KB/s) \\
\hline GK1 - Sipil & 1.1370 & 10.0960 \\
\hline GK2 - Mesin & 3.5753 & 31.7460 \\
\hline GK3 - Kimia_AK & 47.3801 & 420.6940 \\
\hline GK4 - Adm & 3.9725 & 35.2729 \\
\hline GK5 - Elektro & 4.0843 & 36.2654 \\
\hline GK6 - TK MI & 9.9662 & 88.4914 \\
\hline KPA & 29.8842 & 265.3455 \\
\hline
\end{tabular}

Tabel 8. Hasil pengujian Hari Selasa Sore

\begin{tabular}{|c|c|c|}
\hline Gedung & Kapasitas Bandwidth (\%) & Kapasitas Bandwidth (KB/s) \\
\hline GK1 - Sipil & 0.6721 & 9.5269 \\
\hline GK2 - Mesin & 5.0314 & 71.3104 \\
\hline GK3 - Kimia_AK & 25.7121 & 364.4189 \\
\hline GK4 - Adm & 0.2242 & 3.1779 \\
\hline GK5 - Elektro & 35.9693 & 509.7933 \\
\hline GK6 - TK_MI & 2.4033 & 34.0624 \\
\hline KPA & 29.9872 & 425.0100 \\
\hline
\end{tabular}

Tabel 9. Hasil pengujian Hari Rabu Pagi

\begin{tabular}{|c|c|c|}
\hline Gedung & Jumlah bandwidth (\%) & Jumlah bandwidth (KB) \\
\hline GK1 - Sipil & 1.5039 & 7.5196 \\
\hline GK2 - Mesin & 6.3340 & 31.6701 \\
\hline GK3 - Kimia_AK & 66.9012 & 334.5062 \\
\hline GK4 - Adm & 1.1880 & 5.94 \\
\hline GK5 - Elektro & 3.5921 & 17.9605 \\
\hline GK6 - TK_MI & 5.6392 & 28.196 \\
\hline KPA & 14.8414 & 74.2072 \\
\hline
\end{tabular}

Tabel 10. Hasil pengujian Hari Rabu Siang

\begin{tabular}{|c|c|c|}
\hline Gedung & Kapasitas Bandwidth (\%) & Kapasitas Bandwidth (KB/s) \\
\hline GK1 - Sipil & 2.0802 & 18.7927 \\
\hline GK2 - Mesin & 3.6868 & 33.3055 \\
\hline GK3 - Kimia_AK & 33.5533 & 303.1093 \\
\hline GK4 - Adm & 2.2772 & 20.5719 \\
\hline GK5 - Elektro & 8.1844 & 73.9352 \\
\hline GK6 - TK_MI & 22.9676 & 207.4815 \\
\hline KPA & 27.2502 & 246.1697 \\
\hline
\end{tabular}

Tabel 11. Hasil pengujian Hari Rabu Sore

\begin{tabular}{|c|c|c|}
\hline Gedung & Kapasitas Bandwidth (\%) & Kapasitas Bandwidth (KB/s) \\
\hline GK1 - Sipil & 2.5903 & 22.8481 \\
\hline GK2 - Mesin & 10.0467 & 88.6161 \\
\hline GK3 - Kimia_AK & 39.2063 & 345.8148 \\
\hline GK4 - Adm & 0.2051 & 1.80931 \\
\hline GK5 - Elektro & 0.6866 & 6.0565 \\
\hline GK6 - TK MI & 2.7347 & 24.1217 \\
\hline KPA & 44.5299 & 392.771 \\
\hline
\end{tabular}


Tabel 12. Hasil pengujian Hari Kamis Pagi

\begin{tabular}{|c|c|c|}
\hline Gedung & Kapasitas Bandwidth $\%)$ & Kapasitas Bandwidth (KB/s) \\
\hline GK1 - Sipil & 0.9406 & 13.7231 \\
\hline GK2 - Mesin & 3.4726 & 50.6639 \\
\hline GK3 - Kimia_AK & 34.7843 & 507.4810 \\
\hline GK4 - Adm & 51.3819 & 749.6291 \\
\hline GK5 - Elektro & 0.9336 & 13.6210 \\
\hline GK6 - TK_MI & 2.5526 & 37.2416 \\
\hline KPA & 5.9341 & 86.5746 \\
\hline
\end{tabular}

Tabel 13. Hasil pengujian Hari Kamis Siang

\begin{tabular}{|c|c|c|}
\hline Gedung & Kapasitas Bandwidth (\%) & Kapasitas Bandwidth (KB/s) \\
\hline GK1 - Sipil & 1.2579 & 16.4292 \\
\hline GK2 - Mesin & 4.3368 & 56.6419 \\
\hline GK3 - Kimia_AK & 35.0605 & 457.91175 \\
\hline GK4 - Adm & 0.4070 & 5.3166 \\
\hline GK5 - Elektro & 3.2130 & 41.9646 \\
\hline GK6 - TK MI & 4.0786 & 53.2694 \\
\hline KPA & 51.6458 & 674.5247 \\
\hline
\end{tabular}

Tabel 14. Hasil pengujian Hari Kamis Sore

\begin{tabular}{|c|c|c|}
\hline Gedung & Kapasitas Bandwidth (\%) & Kapasitas Bandwidth (KB/s) \\
\hline GK1 - Sipil & 1.5965 & 10.2395 \\
\hline GK2 - Mesin & 2.8154 & 18.0568 \\
\hline GK3 - Kimia_AK & 40.7252 & 261.1860 \\
\hline GK4 - Adm & 0.4078 & 2.615375 \\
\hline GK5 - Elektro & 5.3914 & 34.5773 \\
\hline GK6 - TK_M & 2.9291 & 18.7854 \\
\hline KPA & 46.1343 & 295.8763 \\
\hline
\end{tabular}

Tabel 15. Hasil pengujian Hari Jumat Pagi

\begin{tabular}{|c|c|c|}
\hline Gedung & Kapasitas Bandwidth (\%) & Kapasitas Bandwidth (KB/s) \\
\hline GK1 - Sipil & 0.5815 & 6.3165 \\
\hline GK2 - Mesin & 3.9731 & 43.1559 \\
\hline GK3 - Kimia_AK & 84.6723 & 919.7083 \\
\hline GK4 - Adm & 0.8531 & 9.2666 \\
\hline GK5 - Elektro & 1.8443 & 20.0333 \\
\hline GK6 - TK MI & 2.2857 & 24.8272 \\
\hline KPA & 5.7898 & 62.8889 \\
\hline
\end{tabular}

Tabel 16. Hasil pengujian Hari Jumat Siang

\begin{tabular}{|c|c|c|}
\hline Gedung & Kapasitas Bandwidth (\%) & Kapasitas Bandwidth (KB/s) \\
\hline GK1 - Sipil & 1.3249 & 30.6121 \\
\hline GK2 - Mesin & 3.5970 & 83.1057 \\
\hline GK3 - Kimia_AK & 35.1135 & 811.2537 \\
\hline GK4 - Adm & 0.6188 & 14.2966 \\
\hline GK5 - Elektro & 3.0180 & 69.7291 \\
\hline GK6 - TK MI & 2.1530 & 49.7443 \\
\hline KPA & 54.1743 & 1251.6278 \\
\hline
\end{tabular}

Tabel 17. Hasil pengujian Hari Jumat Sore

\begin{tabular}{|c|c|c|}
\hline Gedung & Kapasitas Bandwidth $(\%)$ & Kapasitas Bandwidth (KB/s) \\
\hline GK1 - Sipil & 0.7425 & 8.0551 \\
\hline GK2 - Mesin & 1.41506 & 15.3493 \\
\hline GK3 - Kimia_AK & 65.5247 & 710.7844 \\
\hline GK4 - Adm & 19.7728 & 214.4873 \\
\hline GK5 - Elektro & 4.0123 & 43.5238 \\
\hline GK6 - TK MI & 1.9204 & 20.8325 \\
\hline KPA & 6.6120 & 71.7243 \\
\hline
\end{tabular}

Tabel 18. Hasil pengujian Hari Sabtu Pagi

\begin{tabular}{|c|c|c|}
\hline Gedung & Kapasitas Bandwidth (\%) & Kapasitas Bandwidth (KB/s) \\
\hline GK1 - Sipil & 1.2391 & 12.6808 \\
\hline GK2 - Mesin & 4.4572 & 45.6133 \\
\hline GK3 - Kimia_AK & 44.1019 & 451.3190 \\
\hline GK4 - Adm & 1.7260 & 17.6640 \\
\hline GK5 - Elektro & 3.3229 & 34.0058 \\
\hline GK6 - TK_MI & 38.7673 & 396.7264 \\
\hline KPA & 6.3852 & 65.3435 \\
\hline
\end{tabular}

Tabel 19. Hasil pengujian Hari Sabtu Siang

\begin{tabular}{|c|c|c|}
\hline Gedung & Kapasitas Bandwiddt (\%) & Kapasitas Bandwidth (KB/s) \\
\hline GK1 - Sipil & 6.6387 & 31.7635 \\
\hline GK2 - Mesin & 10.7200 & 51.2910 \\
\hline GK3 - Kimia_AK & 33.5182 & 160.3709 \\
\hline GK4 - Adm & 15.8758 & 75.959 \\
\hline GK5 - Elektro & 14.77963 & 70.7146 \\
\hline GK6 - TK MI & 3.85004 & 18.4208 \\
\hline KPA & 14.6173 & 69.9381 \\
\hline
\end{tabular}

Tabel 20. Hasil pengujian Hari Sabtu Sore

\begin{tabular}{|c|c|c|}
\hline Gedung & Kapasitas Bandwidth $(\%)$ & Kapasitas Bandwidth (KB/s) \\
\hline GK1 - Sipil & 2.6333 & 17.4192 \\
\hline GK2 - Mesin & 5.2290 & 34.5890 \\
\hline GK3 - Kimia_AK & 56.7741 & 375.5483 \\
\hline GK4 - Adm & 0.7197 & 4.7606 \\
\hline GK5 - Elektro & 7.9839 & 52.8118 \\
\hline GK6 - TK MI & 5.4616 & 36.1274 \\
\hline KPA & 21.1981 & 140.2207 \\
\hline
\end{tabular}

\subsubsection{Analisa Hasil Pengujian Optimasi penggunaan Bandwidth}

Hasil pengujian data kebutuhan bandwidth selama 3 bulan dari bulan Januari sampai bulan Maret 2012 dan di kelompokan berdasarkan hari yaitu hari senin sampai sabtu dan berdasarkan waktu yaitu pagi siang dan sore. Sedangkan data aktual untuk data verifikasi yaitu data pengguna bandwidth selama dua minggu terakhir yaitu data dari tanggal 22 April sampai tanggal 5 Mei 2012 seperti tabel 21 sampai dengan tabel 38.

Tabel 21. Data Hasil Verifikasi Hari Senin Pagi

\begin{tabular}{|c|c|c|c|c|}
\hline HARI & LOKASI & $\begin{array}{l}\text { DATA PREDIKSI } \\
\text { DENGAN FUZZY }\end{array}$ & $\begin{array}{c}\text { DATA } \\
\text { AKTUAL }\end{array}$ & MAPE \\
\hline \multirow{7}{*}{ SENN } & GK1 SIPIL & 46.1105 & 47.1009 & 2.1027 \\
\hline & GK2 MESIN & 43.9784 & 39.3276 & 11.826 \\
\hline & GK3 KIMA/AK & 437.8273 & 442.113 & 0.9694 \\
\hline & GK4 ADM & 7.79 & 6.80192 & 14.527 \\
\hline & GK5 ELEKTRO & 16.7545 & 15.8218 & 5.8947 \\
\hline & GK6 TK/M & 62.3108 & 58.0267 & 7.3831 \\
\hline & G KPA & 83.3288 & 74.3356 & 12.098 \\
\hline \multicolumn{4}{|l|}{$a-1+1$} & 7.8287 \\
\hline
\end{tabular}

Tabel 22. Data Hasil Verifikasi Hari Senin Siang

\begin{tabular}{|c|c|c|c|c|}
\hline HARI & LOKASI & $\begin{array}{l}\text { DATA PREDIKSI } \\
\text { DENGAN FUZZY }\end{array}$ & $\begin{array}{c}\text { DATA } \\
\text { AKTUAL }\end{array}$ & MAPE \\
\hline \multirow{7}{*}{ SENIN } & GK1 SIPIL & 47.1009 & 38.6826 & 21.763 \\
\hline & GK2MESIN & 39.3275 & 78.8598 & 50.13 \\
\hline & GK3 KIMA/AK & 442.1133 & 405.682 & 8.9801 \\
\hline & GK4 ADM & 6.8019 & 15.2014 & 55.255 \\
\hline & GK5 ELEKTRO & 15.8218 & 23.7503 & 33.383 \\
\hline & GK6 TK/M & 58.0266 & 94.4421 & 38.559 \\
\hline & G KPA & 74.3355 & 150.778 & 50.699 \\
\hline \multicolumn{4}{|c|}{ Rata-tata } & 36.967 \\
\hline
\end{tabular}


Tabel 23. Data Hasil Verifikasi Hari Senin Sore

\begin{tabular}{|c|c|c|c|c|}
\hline HARI & LOKASI & $\begin{array}{c}\text { DATA PREDIKSI } \\
\text { DENGAN FUZZY }\end{array}$ & $\begin{array}{c}\text { DATA } \\
\text { AKTUAL }\end{array}$ & MAPE \\
\hline \multirow{5}{*}{ SENN } & GK1 SIPIL & 31.1692 & 27.4126 & 13.704 \\
\cline { 2 - 5 } & GK2 MESIN & 67.641 & 62.0316 & 9.0427 \\
\cline { 2 - 5 } & GK3 KIMANAK & 359.4962427 & 336.403 & 6.8647 \\
\cline { 2 - 5 } & GK4 ADM & 7.84055 & 375.548 & 97.912 \\
\cline { 2 - 5 } & GK5 ELEKIRO & 49.4261 & 62.2641 & 20.619 \\
\cline { 2 - 5 } & GK6 TK/M & 72.0375 & 60.8353 & 18.414 \\
\cline { 2 - 5 } & G KPA & 191.453 & 211.79 & 9.6026 \\
\hline Rata-tata ta & \multicolumn{4}{|c|}{25.166} \\
\hline
\end{tabular}

Tabel 24. Data Hasil Verifikasi Hari Selasa Pagi

\begin{tabular}{|c|c|c|c|c|}
\hline HARI & LOKASI & $\begin{array}{c}\text { DATA PREDIKSI } \\
\text { DENGAN FUZZY }\end{array}$ & $\begin{array}{c}\text { DATA } \\
\text { AKTUAL }\end{array}$ & MAPE \\
\hline \multirow{5}{*}{ SELASA } & GK1 SIPIL & 5.8324 & 5.832491 & 0.0016 \\
\cline { 2 - 5 } & GK2 MESIN & 42.2769 & 42.27691 & $3 \mathrm{E}-05$ \\
\cline { 2 - 5 } & GK3 KIMIA/AK & 411.1901 & 411.1901 & $2 \mathrm{E}-06$ \\
\cline { 2 - 5 } & GK4 ADM & 21.8278 & 21.82784 & 0.0002 \\
\cline { 2 - 5 } & GK5 ELEKIRO & 24.0714 & 24.07146 & 0.0002 \\
\cline { 2 - 5 } & GK6 TKMI & 49.1478 & 49.14786 & 0.0001 \\
\cline { 2 - 5 } & G KPA & 666.1142 & 666.1143 & $1 \mathrm{E}-05$ \\
\hline Rata-rata & \multicolumn{4}{|c|}{0.0003} \\
\hline
\end{tabular}

Tabel 25. Data Hasil Verifikasi Hari Selasa Siang

\begin{tabular}{|c|c|c|c|c|}
\hline HARI & LOKASI & $\begin{array}{l}\text { DATA PREDIKSI } \\
\text { DENGAN FUZZY }\end{array}$ & $\begin{array}{c}\text { DATA } \\
\text { AKTUAL }\end{array}$ & MAPE \\
\hline \multirow{7}{*}{ SELASA } & GK1 SIPIL & 10.096 & 10.09609 & 0.0008 \\
\hline & GK2 MESIN & 31.746 & 31.74609 & 0.0003 \\
\hline & GK3 KIMA/AK & 420.694 & 420.694 & $1 \mathrm{E}-06$ \\
\hline & GK4 ADM & 35.2729 & 35.27299 & 0.0003 \\
\hline & GK5 ELEKTRO & 36.2654 & 36.26543 & $9 \mathrm{E}-05$ \\
\hline & GK6 TKMI & 88.4914 & 88.49145 & $6 \mathrm{E}-05$ \\
\hline & G KPA & 265.3455 & 265.3456 & $2 \mathrm{E}-05$ \\
\hline \multicolumn{4}{|l|}{ Rata-rata } & 0.0002 \\
\hline
\end{tabular}

Tabel 26. Data Hasil Verifikasi Hari Selasa Sore

\begin{tabular}{|c|c|c|c|c|}
\hline HARI & LOKASI & $\begin{array}{c}\text { DATA PREDIKSI } \\
\text { DENGAN FUZZY }\end{array}$ & $\begin{array}{c}\text { DATA } \\
\text { AKTUAL }\end{array}$ & MAPE \\
\hline \multirow{5}{*}{ SELASA } & GK1 SIPIL & 9.5269 & 9.52692 & 0.0002 \\
\cline { 2 - 5 } & GK2 MESIN & 71.3104 & 71.31042 & $3 \mathrm{E}-05$ \\
\cline { 2 - 5 } & GK3 KIMA/AK & 364.4189 & 364.419 & $3 \mathrm{E}-05$ \\
\cline { 2 - 5 } & GK4 ADM & 3.1779 & 3.177952 & 0.0016 \\
\cline { 2 - 5 } & GK5 ELEKTRO & 509.7933 & 509.7934 & $2 \mathrm{E}-05$ \\
\cline { 2 - 5 } & GK6 TK/M & 34.0624 & 34.06249 & 0.0003 \\
\cline { 2 - 5 } & G KPA & 425.01 & 425.01 & $1 \mathrm{E}-05$ \\
\hline Rata-rata & \multicolumn{3}{|l}{} & 0.0003 \\
\hline
\end{tabular}

Tabel 27. Data Hasil Verifikasi Hari Rabu Pagi

\begin{tabular}{|c|c|c|c|c|}
\hline HARI & LOKASI & $\begin{array}{l}\text { DATA PREDIKSI } \\
\text { DENGAN FUZZY }\end{array}$ & $\begin{array}{c}\text { DATA } \\
\text { AKTUAL }\end{array}$ & MAPE \\
\hline \multirow{7}{*}{ RABU } & GK1 SPIL & 7.5196 & 10.2268 & 26.472 \\
\hline & GK2 MESIN & 31.6701 & 36.8255 & 14 \\
\hline & GK3 KMIA/AK & 334.5062 & 354.389 & 5.6104 \\
\hline & GK4 ADM & 5.94 & 18.0772 & 67.141 \\
\hline & GK5 ELEKTRO & 17.9605 & 44.7366 & 59.853 \\
\hline & GK6 TKMI & 28.196 & 200.58 & 85.943 \\
\hline & G KPA & 74.2072 & 207.63 & 64.26 \\
\hline \multicolumn{4}{|c|}{ Rata-rata } & 46.183 \\
\hline
\end{tabular}

Tabel 28. Data Hasil Verifikasi Hari Rabu Siang

\begin{tabular}{|c|c|c|c|c|}
\hline HARI & LOKASI & $\begin{array}{l}\text { DATA PREDIKSI } \\
\text { DENGAN FUZZY }\end{array}$ & $\begin{array}{r}\text { DATA } \\
\text { AKTUAL }\end{array}$ & MAPE \\
\hline \multirow{7}{*}{ RABU } & GK1 SPIL & 18.7927 & 18.7927 & $2 \mathrm{E}-05$ \\
\hline & GK2 MESIN & 33.3055 & 33.3056 & 0.0002 \\
\hline & GK3 KMIA/AK & 303.1093 & 303.109 & $3 \mathrm{E}-05$ \\
\hline & GK4 ADM & 20.5719 & 20.5719 & 0.0001 \\
\hline & GK5 ELEKTRO & 73.9352 & 73.9352 & 1E-05 \\
\hline & GK6 TKMI & 207.4815 & 207.482 & $4 \mathrm{E}-05$ \\
\hline & G KPA & 246.1697 & 246.17 & $3 \mathrm{E}-05$ \\
\hline \multicolumn{4}{|l|}{ Rata-rata } & $7 \mathrm{E}-05$ \\
\hline
\end{tabular}

Tabel 29. Data Hasil Verifikasi Hari Rabu Sore

\begin{tabular}{|c|c|c|c|c|}
\hline HARI & LOKASI & $\begin{array}{l}\text { DATA PREDIKSI } \\
\text { DENGAN FUZZY }\end{array}$ & $\begin{array}{c}\text { DATA } \\
\text { AKTUAL }\end{array}$ & MAPE \\
\hline \multirow{7}{*}{ RABU } & GK1 SPIL & 22.8481 & 22.8481 & $5 \mathrm{E}-05$ \\
\hline & GK2MESIN & 88.6161 & 88.6161 & $9 \mathrm{E}-06$ \\
\hline & GK3 KMAA/AK & 345.8148 & 345.815 & $2 \mathrm{E}-05$ \\
\hline & GK4 ADM & 1.8093 & 1.80935 & 0.003 \\
\hline & GK5 ELEKTRO & 6.0565 & 6.05651 & 0.0002 \\
\hline & GK6 TKMI & 24.1217 & 24.1217 & 0.0001 \\
\hline & G KPA & 392.7716 & 392.772 & $7 \mathrm{E}-06$ \\
\hline \multicolumn{4}{|l|}{ Rata-rata } & 0.0005 \\
\hline
\end{tabular}

Tabel 30. Data Hasil Verifikasi Hari Kamis Pagi

\begin{tabular}{|c|c|c|c|c|}
\hline HARI & LOKASI & $\begin{array}{l}\text { DATA PREDIKSI } \\
\text { DENGAN FUZZY }\end{array}$ & $\begin{array}{c}\text { DATA } \\
\text { AKTUAL }\end{array}$ & MAPE \\
\hline \multirow{7}{*}{ KAMS } & GK1 SIPIL & 13.7231 & 13.7231 & $1 \mathrm{E}-04$ \\
\hline & GK2 MESIN & 50.6639 & 50.6639 & $7 \mathrm{E}-05$ \\
\hline & GK3 KIMA/AK & 507.481 & 507.481 & $1 \mathrm{E}-05$ \\
\hline & GK4 ADM & 749.6291 & 749.629 & $8 \mathrm{E}-06$ \\
\hline & GK5 ELEKTRO & 13.621 & 13.6211 & 0.0004 \\
\hline & GK6 TK/M & 37.2416 & 37.2416 & $9 \mathrm{E}-05$ \\
\hline & G KPA & 86.5746 & 86.5747 & $8 E-05$ \\
\hline \multicolumn{4}{|l|}{ Rata-tata } & 0.0001 \\
\hline
\end{tabular}

Tabel 31. Data Hasil Verifikasi Hari Kamis Siang

\begin{tabular}{|c|c|c|c|c|}
\hline HARI & LOKASI & $\begin{array}{l}\text { DATA PREDIKSI } \\
\text { DENGAN FUZZY }\end{array}$ & $\begin{array}{c}\text { DATA } \\
\text { AKTUAL }\end{array}$ & MAPE \\
\hline \multirow{7}{*}{ KAMS } & GK1 SIPIL & 16.4292 & 16.4293 & 0.0006 \\
\hline & GK2 MESIN & 56.6419 & 56.6419 & $8 \mathrm{E}-05$ \\
\hline & GK3 KIMA/AK & 457.9117 & 457.912 & $6 \mathrm{E}-07$ \\
\hline & GK4 ADM & 5.3166 & 5.31663 & 0.0005 \\
\hline & GK5 ELEKTRO & 41.9646 & 41.9647 & 0.0002 \\
\hline & GK6 TK/M & 53.2694 & 53.2694 & $1 \mathrm{E}-05$ \\
\hline & G KPA & 674.5247 & 674.525 & $1 \mathrm{E}-05$ \\
\hline \multicolumn{4}{|l|}{ Rata-tata } & 0.0002 \\
\hline
\end{tabular}

Tabel 32. Data Hasil Verifikasi Hari Kamis Sore

\begin{tabular}{|c|c|c|c|c|}
\hline HARI & LOKASI & $\begin{array}{l}\text { DATA PREDIKSI } \\
\text { DENGAN FUZZY }\end{array}$ & $\begin{array}{c}\text { DATA } \\
\text { AKTUAL }\end{array}$ & MAPE \\
\hline \multirow{7}{*}{ KAMS } & GK1 SIPIL & 10.2395 & 10.2395 & 0.0003 \\
\hline & GK2 MESIN & 18.0568 & 18.0568 & $4 \mathrm{E}-05$ \\
\hline & GK3 KIMA/AK & 261.186 & 261.186 & $3 \mathrm{E}-05$ \\
\hline & GK4 ADM & 2.6153 & 2.61538 & 0.0029 \\
\hline & GK5 ELEKTRO & 34.5773 & 34.5773 & $5 \mathrm{E}-05$ \\
\hline & GK6 TK/M & 18.7854 & 18.7854 & 0.0002 \\
\hline & G KPA & 295.8763 & 295.876 & 9E-06 \\
\hline \multicolumn{4}{|l|}{$a-18$} & 0.0005 \\
\hline
\end{tabular}


Tabel 33. Data Hasil Verifikasi Hari Jumat Pagi

\begin{tabular}{|c|c|c|c|c|}
\hline HARI & LOKASI & $\begin{array}{l}\text { DATA PREDIKSI } \\
\text { DENGAN FUZZY }\end{array}$ & $\begin{array}{c}\text { DATA } \\
\text { AKTUAL }\end{array}$ & MAPE \\
\hline \multirow{7}{*}{ JUMAT } & GK1 SIPIL & 6.3165 & 6.31655 & 0.0007 \\
\hline & GK2 MESIN & 43.1559 & 43.156 & 0.0002 \\
\hline & GK3 KIMA/AK & 919.7083 & 919.708 & 0 \\
\hline & GK4 ADM & 9.2666 & 9.70793 & 4.5461 \\
\hline & GK5 ELEKTRO & 20.0333 & 20.0333 & 0.0001 \\
\hline & GK6 TK/M & 24.8272 & 24.8273 & 0.0004 \\
\hline & G KPA & 62.8889 & 62.8889 & $6 \mathrm{E}-05$ \\
\hline \multicolumn{4}{|l|}{ Rata-rata } & 0.6496 \\
\hline
\end{tabular}

Tabel 34. Data Hasil Verifikasi Hari Jumat Siang

\begin{tabular}{|c|c|c|c|c|}
\hline HARI & LOKASI & $\begin{array}{l}\text { DATA PREDIKSI } \\
\text { DENGAN FUZZY }\end{array}$ & $\begin{array}{c}\text { DATA } \\
\text { AKTUAL }\end{array}$ & MAPE \\
\hline \multirow{7}{*}{ JUMAT } & GK1 SIPIL & 30.6121 & 30.6121 & 0.0002 \\
\hline & GK2 MESIN & 83.1057 & 83.1057 & $4 \mathrm{E}-06$ \\
\hline & GK3 KIMA/AK & 811.2537 & 811.254 & $7 \mathrm{E}-06$ \\
\hline & GK4 ADM & 14.2966 & 14.2966 & 0.0002 \\
\hline & GK5 ELEKTRO & 69.7291 & 69.7292 & 0.0001 \\
\hline & GK6 TK/M & 49.7443 & 49.7444 & 0.0002 \\
\hline & GKPA & 1251.6278 & 1251.63 & $1 \mathrm{E}-06$ \\
\hline \multicolumn{4}{|l|}{ Rata-tata } & $9 \mathrm{E}-05$ \\
\hline
\end{tabular}

Tabel 35. Data Hasil Verifikasi Hari Jumat Sore

\begin{tabular}{|c|c|c|c|c|}
\hline HARI & LOKASI & $\begin{array}{l}\text { DATA PREDIKSI } \\
\text { DENGAN FUZZY }\end{array}$ & $\begin{array}{c}\text { DATA } \\
\text { AKTUAL }\end{array}$ & MAPE \\
\hline \multirow{7}{*}{ JMAT } & GK1 SIPIL & 8.0551 & 8.05518 & 0.0009 \\
\hline & GK2 MESIN & 15.3493 & 15.3494 & 0.0005 \\
\hline & GK3 KIMA/AK & 710.7844 & 710.784 & $8 \mathrm{E}-06$ \\
\hline & GK4 ADM & 214.4873 & 214.487 & $3 \mathrm{E}-05$ \\
\hline & GK5 ELEKTRO & 43.5238 & 43.5239 & 0.0002 \\
\hline & GK6 TK/M & 20.8325 & 20.8325 & 0.0001 \\
\hline & G KPA & 71.7243 & 71.7243 & $7 \mathrm{E}-05$ \\
\hline \multicolumn{4}{|l|}{ Rata-rata } & 0.0003 \\
\hline
\end{tabular}

Tabel 36. Data Hasil Verifikasi Hari Sabtu Pagi

\begin{tabular}{|c|c|c|c|c|}
\hline HARI & LOKASI & $\begin{array}{l}\text { DATA PREDIKSI } \\
\text { DENGAN FUZZY }\end{array}$ & $\begin{array}{c}\text { DATA } \\
\text { AKTUAL }\end{array}$ & MAPE \\
\hline \multirow{7}{*}{ SABTU } & GK1 SIPIL & 12.6808 & 12.6809 & 0.0007 \\
\hline & GK2 MESIN & 45.6133 & 45.6134 & 0.0001 \\
\hline & GK3 KIMA/AK & 451.319 & 451.319 & $1 \mathrm{E}-05$ \\
\hline & GK4 ADM & 17.664 & 17.664 & 0.0002 \\
\hline & GK5 ELEKTRO & 34.0058 & 34.0058 & $6 \mathrm{E}-06$ \\
\hline & GK6 TKMI & 396.7264 & 396.726 & $2 \mathrm{E}-05$ \\
\hline & G KPA & 65.3435 & 65.3436 & $8 E-05$ \\
\hline \multicolumn{4}{|l|}{ Rata-tata } & 0.0002 \\
\hline
\end{tabular}

Tabel 37. Data Hasil Verifikasi Hari Sabtu Siang

\begin{tabular}{|c|c|c|c|c|}
\hline HARI & LOKASI & $\begin{array}{l}\text { DATA PREDIKSI } \\
\text { DENGAN FUZZY }\end{array}$ & $\begin{array}{c}\text { DATA } \\
\text { AKTUAL }\end{array}$ & MAPE \\
\hline \multirow{7}{*}{ SABTU } & GK1 SIPIL & 31.7635 & 31.7636 & 0.0002 \\
\hline & GK2 MESIN & 51.291 & 51.2911 & 0.0002 \\
\hline & GK3 KIMIA/AK & 160.3709 & 160.371 & 4E- -05 \\
\hline & GK4 ADM & 75.9593 & 75.9594 & 9E-05 \\
\hline & GK5 ELEKTRO & 70.7146 & 70.7146 & $4 \mathrm{E}-05$ \\
\hline & GK6 TKMI & 18.4208 & 18.4208 & $9 \mathrm{E}-05$ \\
\hline & G KPA & 69.9381 & 69.9382 & 8E-05 \\
\hline \multicolumn{4}{|l|}{ Rata-tata } & $1 \mathrm{E}-04$ \\
\hline
\end{tabular}

Tabel 38. Data Hasil Verifikasi Hari Sabtu Sore

\begin{tabular}{|c|c|c|c|c|}
\hline HARI & LOKASI & $\begin{array}{l}\text { DATA PREDIKSI } \\
\text { DENGAN FUZZY }\end{array}$ & $\begin{array}{c}\text { DATA } \\
\text { AKTUAL }\end{array}$ & MAPE \\
\hline \multirow{7}{*}{ SABTU } & GK1 SIPIL & 17.4192 & 17.4193 & 0.0006 \\
\hline & GK2 MESIN & 34.589 & 34.5891 & 0.0002 \\
\hline & GK3 KIMIA/AK & 375.5483 & 375.548 & $2 \mathrm{E}-05$ \\
\hline & GK4 ADM & 4.7606 & 4.76068 & 0.0016 \\
\hline & GK5 ELEKTRO & 52.8118 & 52.8118 & $2 \mathrm{E}-05$ \\
\hline & GK6 TKMI & 36.1274 & 36.1275 & 0.0001 \\
\hline & G KPA & 140.2207 & 140.221 & $5 \mathrm{E}-05$ \\
\hline \multicolumn{4}{|l|}{ Rata-lata } & 0.0004 \\
\hline
\end{tabular}

Pada penelitian ini di peroleh kesalahan rata-rata MAPE (Means Absolute Percentage Error) didapat dari data pada tabel 4.20 sampai dengan tabel 4.37 yaitu :

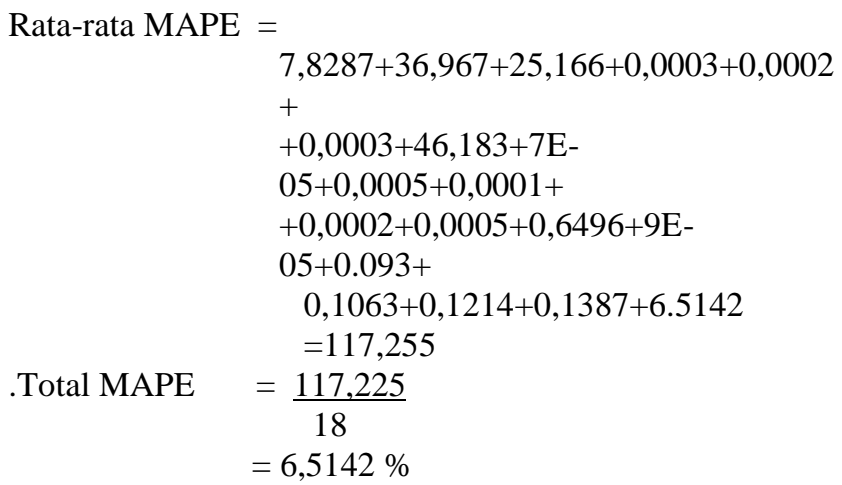

Untuk menghitung kesalahan rata-rata MAPE menggunakan persamaan (2). Dengan kesalahan rata-rata $6,5142 \%$ maka hasil simulasi dapat diterima secara memuaskan.

\section{Kesimpulan} berikut:

Penelitian ini, diperoleh beberapa kesimpulan sebagai

1. Dengan sistem pakar fuzzy diperoleh informasi untuk optimasi penggunaan bandwidth pada setiap hari dan waktu yang sama.

2. Sistem pakar fuzzy dengan metode Sugeno dapat digunakan untuk optimasi penggunaan bandwidth dengan cara membuat rule base untuk sistem fuzzy yang outputnya informasi pemakaian bandwith pada setiap gedung kuliah.

\section{Saran}

Berdasarkan hasil penelitian berupa sistem informasi optimasi penggunaan bandwidth dengan metode sistem pakar fuzzy dapat digunakan sebagai acuan untuk penentuan kebutuhan bandwidth sehingga dapat dimanfaatkan oleh administrator jaringan atau Kepala Bagian IT untuk menentukan berapa besar bandwith untuk setiap gedungnya, sehingga dapat menyewa bandwith sesuai kebutuhan. 


\section{Daftar Pustaka}

Agus, F., Suyatno, A. dan Supianto, 2010. Optimalisasi manajemen bandwidth pada jaringan intranet Universitas Mulawarman. Jurnal Informatika Mulawarman, 5: 27-35.

Andrew, S., 1997. Jaringan Komputer Edisi Bahasa Indonesia Jilid I, Jakarta : Prenhallindo.

Fiengo, Giovanni, G., Edmondo, T., 2007. Neural-based downlink scheduling algorithm for broadband wireless networks. Computer Communications, 30: 207-218.

Foster, I. and Kesselman, C., 2003. The Grid: Blueprint for a New Computing Infrastructure, Second edition, California: Morgan Kaufman.

Hany, I., Fahmy and Christos, D., 1999. Applications of hybrid fuzzy expert systems in computer networks design. IEEE Proceedings, 4 $1-22$

Hartati, S. dan Iswanti, S, 2008. Sistem Pakar dan Pengembangannya Yogyakarta : Graha Ilmu.

Hirin, A.M., 2011, Belajar Tuntas VB.Net 2010, Jakarta : Prestasi Pustaka Jumingan, 2009. Studi Kelayakan Bisnis, Teori dan Proposal Kelayakan. Jakarta : Bumi Aksara.
Keles, A., 2008. ESTDD: Expert system for thyroid diseases diagnosis. Expert Systems with Applications, 34: 242-246.

Nandi, B., Vasarhelyi, M.A. and Ahn, J.H., 1998. Network demand model and global Internet traffic forecasting, Jae-Hyeon Ahn, K, 12 : $1-22$.

Romano, F., Giovanni, G., 2002. A Fuzzy Logic-based Resource Management Scheme for High-quality Broadband Wireless Access Systems, SSGRR, Vol. 2002W Page 21-27.

Oktafri, 2001. Aplikasi Metode Simulasi Monte Carlo Untuk Menduga Debit Aliran Sungai, Fakultas Pertanian Universitas Lampung, 15: 72 -79 .

Santoso, L.W., Intan, R., Sugianto, F., 2008. Implementasi Fuzzy Expert System Untuk Analisa Penyakit Dalam Pada Manusia. Yogyakarta Seminar Nasional Aplikasi Teknologi Informasi (SNATI 2008).

Kusumadewi, S., Hari, P., 2010. Aplikasi Logika Fuzzy Untuk Pendukung Keputusan. Yogyakarta, Graha Ilmu.

Trimantaraningsih, R.., Muarifah, 2008. Implementasi Mikrotik Sebagai Manajemen Bandwidth, FTI AKPRIND, 1: 283-295.

Yaxin, C., Victor, O.K., Li, F., 2001. Scheduling Algorithms in BroadBand Wireless Networks. IEEE PROCEEDINGS, 89: 77-87. 